\title{
RANCANG BANGUN APLIKASI ANDROID POS (POINT OF SALE) KAFE UNTUK KASIR PORTABLE DAN BLUETOOTH PRINTER
}

\author{
${ }^{1}$ Gilang Pamungkas, ${ }^{2}$ Herman Yuliansyah \\ 1,2Program Studi Teknik Informatika Universitas Ahmad Dahlan \\ Jl. Prof. Dr. Soepomo, Janturan, Yogyakarta 55164 \\ E-mail : gpamungkaz@gmail.com, herman.yuliansyah@tif.uad.ac.id
}

\begin{abstract}
Abstrak
Kafe merupakan salah satu jenis usaha di bidang kuliner yang banyak diminati pengunjung. Beberapa permasalahan yang ada adalah sistem transaksi keuangan di kafe belum memanfaatkan kasir digital, hanya berupa mesin drawer. Sehingga terdapat batasan pada perhitungan transaksi. Tujuan dari penelitian menghasilkan aplikasi kasir tablet android untuk membantu proses transaksi penjualan dan dapat merekapitulasi laporan data transaksi di kafe. Selain itu, pada aplikasi ini ditambahkan fitur pencetakan kwitansi untuk pelanggan. Pengujian aplikasi android dilakukan dengan metode unit test dan menunjukkan sudah berjalan dengan lancar dan tidak ada method yang error, sehingga dapat dinyatakan lolos. Selain itu, pengujian black box test dapat disimpulkan bahwa aplikasi berjalan sesuai dengan yang telah dirancang.
\end{abstract}

Kata Kunci: Android, Point Of Sale, Bluetooth Printer, Kafe.

\begin{abstract}
The cafe is one type of business in the culinary field that attracted many visitors. Some of the existing problems is the system of financial transaction in the cafe not utilize digital cashier, just a machine drawer. So there is a limit on the calculation of the transaction. The purpose of the research to produce applications cashier android tablet to help process sales transactions and can recapitulate report transaction data in the cafe. In addition, this application features added printing receipts for customers. Android application testing was conducted using unit tests and show has been running smoothly and there is no method that error, so it can be passed. In addition, black box testing the test can be concluded that the application runs in accordance with the previously designed.
\end{abstract}

Keywords: Android, Point Of Sale, Bluetooth Printer, Cafe.

\section{PENDAHULUAN}

Kafe merupakan salah satu bentuk usaha yang mengedepankan konsep, teste dan pelayanan. Desain sederhana dengan mengguna-kan meja dan bangku kayu panjang seperti di warung makan biasa. Kafe ini buka dari sore hingga malam dan selalu dipenuhi oleh pengunjung yang ratarata anak muda. Sering juga wisatawan dan mahasiswa asing datang ke tempat ini. Menu yang ditawarkan juga bervariasi. Dari kopi robusta hingga cappucino maupun viet coffee. Tidak hanya kopi, tempat ini juga menjual berbagai ramuan teh, susu hingga minuman tradisional semacam wedang uwuh. Sebagai teman minuman tersedia snack ringan seperti keripik tahu, roti/pisang bakar hingga makanan berat seperti nasi goreng. Namun yang khas dari kafe ini adalah makanan khas india yaitu roti maryam. Roti ini berbentuk bulat pipih yang disajikan dengan madu, coklat, keju atau susu kental manis.

Beberapa kafe belum memiliki sistem kasir digital atau masih menggunakan mesin drawer atau dengan pencatatan kertas serta rekapitulasi data transaksi penjualan dan pembelian. Pelanggan memesan makan atau minuman denan cara mendatangi stand khusus yang terdapat daftar makanan maupun minuman dan mengisikan daftar pesanan tersebut ke dalam form khusus yang disediakan kafe. Form tersebut dijadikan bahan rekapitulasi transaksi 
penjuaan dan bukti pembayaran atau struk untuk pelanggan. Rekapitulasi ini dilakukan setelah Kafe tutup dengan cara menginputkan seluruh bukti pemba-yaran penjualan. Dari inputan tran-saksi penjualan tersebut dapat diketahui berapa dan apa saja item yang terjual secara langsung, karena sudah memiliki template khusus untuk rekapitulasi tersebut. Pemilik Kafe merasa kesulitan saat rekapitulasi data karena harus mengin-putkan bukti penjualan serta pembelian secara satu persatu setiap harinya yang disimpan dalam file excel pertransaksi satu sheet dan perhari satu file.

\section{KAJIAN PUSTAKA}

Penelitian terdahulu yang pernah dilakukan oleh Yofi Okta Jeafri dkk, pada tahun 2012 tenteng Aplikasi Financial Record Income berisi penelitian tentang masalah laporan keuangan yang mencakup laba-rugi dan neraca dilakukan secara manual, sehingga terkadang membutuhkan tenaga ahli untuk melakukan perhitungan tersebut. Penelitian lainnya yang pernah dilakukan oleh Muhammad lqbal Merdeka Eka Putra, pada tahun 2012 tentang Aplikasi Penjualan berbasis Android mengenai perhitungan transaksi masih dilakukan menggunakan kalkulator sehingga memakan waktu apabila transaksi yang dilakukan banyak dan akan mengulangi perhitungan dari awal apabila terjadi kesalahan perhitungan. Penelitian lainnya yang pernah dilakukan oleh Dapai Ari Hidayat, pada tahun 2014 tentang Aplikasi Point Of Sale (POS) Berbasis Web mengenai permasalahan yang terjadi pada CV. NMRQ yang akan mengembangkan beberapa cabang sehingga membutuhkan aplikasi web point of sales (POS) sebagai sarana promosi dan manajemen perusahaan agagar dapat menyajikan informasi transaksi - transaksi dan laporan laporan penjualan baik di kantor pusat maupun di kantor cabang secara realtime sehingga dapat dijadikan indikator kesuksesan dan keberhasilan suatu perusahaan dalam menjalankan bisnisnya. Penelitian lainnya yang pernah dilakukan oleh Ahmad Jamal dkk, pada tahun 2013 tentang Aplikasi Kasir Menggunakan Barcode Reader, permasalahan yang terjadi adalah proses pembuatan nota penjualan dan perhitungan jumlah harga penjualan di Toko dan Jasa Widodo Computer Ngadirojo sering terjadi kesalahan yang disebabkan akibat kesalahan manusia. Kelalaian yang dilakukan ketika kasir melakukan pelayanan saat banyak konsumen yang melakukan transaksi pembayaran, sehingga kasir kurang teliti dalam pembuatan nota, perhitungan jumlah total dan pencatatan data ke dalam buku arsip penjualan. Penelitian lainnya yang pernah dilakukan oleh Imanuel Abdi Ridarta Ginting, pada tahun 2011 tentang Aplikasi Point Of Sales (POS) Berbasis Web Pada Distro Previous, menyebutkan permasalahan yang terjadi adalah pencatatan keuangan secara manual dan belum terkomputerisasi, sehingga pemilik usaha harus melihat langsung ke distro untuk mengetahui informasi penjualan pada distronya.

\section{Kafe}

Definisi kafe menurut kamus besar bahasa Indonesia adalah tempat minum kopi yang pengunjungnya dihibur dengan music, tempat minum yg pengunjungnya dapat memesan minuman, seperti kopi, teh, bir, dan kue-kue.

\section{Point Of Sale (POS)}

$P O S$ adalah sebuah sistem yang memungkinkan untuk transaksi, yang didalamnya termasuk juga penggunaan mesin kasir. Dalam lingkup POS, sebuah mesin kasir tidak berdiri sendiri namun sudah termasuk di dalamnya software penunjang dan piranti lain. Sistem $P O S$ melakukan lebih dari sekedar transaksi jual beli, didalamnya juga bisa terintegrasi perhitungan akuntansi, manajemen barang dan stok, modul penggajian karyawan, perhitunga hutang piutang, dan berbagai macam fungsi lainnya.

\section{Android}

Android merupakan sebuah sistem operasi perangkat mobile berbasis linux yang mencakup sistem operasi, middleware, dan apliakasi. Pengembang dengan bebas membuat aplikasi android karena merupakan platform terbuka (Open Source). 4. SQLite Database

SQLite Database merupakan embedded database atau database yang sudah masuk dalam paket yang dapat digunakan pada Android. SQLite dapat dibangun di Android dan memiiki fitur 
relasional database. Untuk dapat menggunakan fitur ini pengembang aplikasi android cukup mendefinisiksan perintah $S Q L$ untuk meng-create atau meng-update database. Selanjutnya sistem pada android akan memahami hal-hal yang berhubungan dengan database. SQLite database akan otomatis tersimpan di dalam path data/data/nama_package/database/ nama database.

5. Eclipse

Eclipse merupakan komunitas open source yang bertujuan mengembangkan platform terbuka. Eclipse terdiri atas framework yang dapat dikemangkan lebih lanjut, peralatan bantu untuk membuat dan mengelola software sejak awal hingga diluncurkan. Eclipse memiliki kemampuan untuk dapat dikembangkan oleh pengguna dengan komponen yang dinamakan plug-in.

\section{METODE PENELITIAN}

Penelitian ini tertuju pada sistem kasir pada sebuah Kafe. Metode penelitian yang digunakan yaitu menggunakan model proses waterfall. adalah:

Tahapan penelitian yang dilakukan

1. Melakukan Analisis Kebutuhan

Pada tahap ini adalah menganalis kebutuhan untuk membangun aplikasi kasir portable android. Kegiatan analisis sistem yang dilakuan mencakup kebutuhan fungsional, kebutuhan nonfungsional, dan use case diagram.

2. Melakukan Rancangan Aplikasi

Pada tahap ini akan melakukan rancangan berupa rancangan data dalam bentuk Entitas Relationship Diagram (ERD), rancangan User Interface, Rancangan pemodelan aplikasi dalam bentuk Activity Diagram.

3. Melakukan Implementasi

Pada tahap ini implementasi dilakukan dengan membuat kode program dari aplikasi dalam bentuk aplikasi Android menggunakan JAVA sebagai bahasa pemrograman.

4. Melakukan Testing

Pengujian aplikasi menggunakan metode unit test, black box test dan alpha test.

5. Melakukan Deployment
Tahap deployment dilakukan dengan melakukan instalasi ke perangkat smartphone dengan sistem operasi android dan melakukan koneksi terhadap printer portable dengan koneksi Bluetooth.

\section{HASIL DAN PEMBAHASAN}

1. Analisis Kebutuhan Sistem

a. Kasir dapat melakukan pengolahan data makanan yang tersedia.

b. Kasir dapat melakukan pengolahan transaksi penjualan.

c. Kasir dapat melakukan pencetakan struk transaksi penjualan.

d. Kasir dapat melihat rekapitulasi laporan penjualan.

2. Kebutuhan Fungsional

a) Melakukan perhitungan secara otomatis saat transaksi berjalan, sehingga kasir dan pelanggan akan mengetahui total biaya yang harus dibayarkan oleh pelanggan.

b) Melakukan perhitungan secara otomatis, sehingga kasir dapat mengetahui jumlah makanan yang terjual dan makanan mana yang paling laris dibeli oleh pelanggan.

c) Melakukan pengolahan data transaksi atau pencatatan laporan pendapatan.

d) Menambah data makanan terkait nama makanan, kategori makanan dan harga jual. Serta dapat mengubah dan menghapus data makanan tersebut.

3. Kebutuhan Non-Fungsional

Aplikasi kasir tablet portable dapat berjalan di smartphone Android dengan memanfaatkan media penyimpanan SQLite Database serta menggunakan printer Bluetooth portable Zjiang. Minimal versi android yang digunakan adalah Android 5.0 Lolipop dengan ukuran layar 7.0".

4. Use Case Diagram

Use case diagram digunakan untuk menggambarkan proses yang dapat dilakukan oleh end-user. Pembuatan use case ini didasarkan pada analisis kebutuhan fungsional. gambar 1 merupakan Use Case Diagram kasir. 


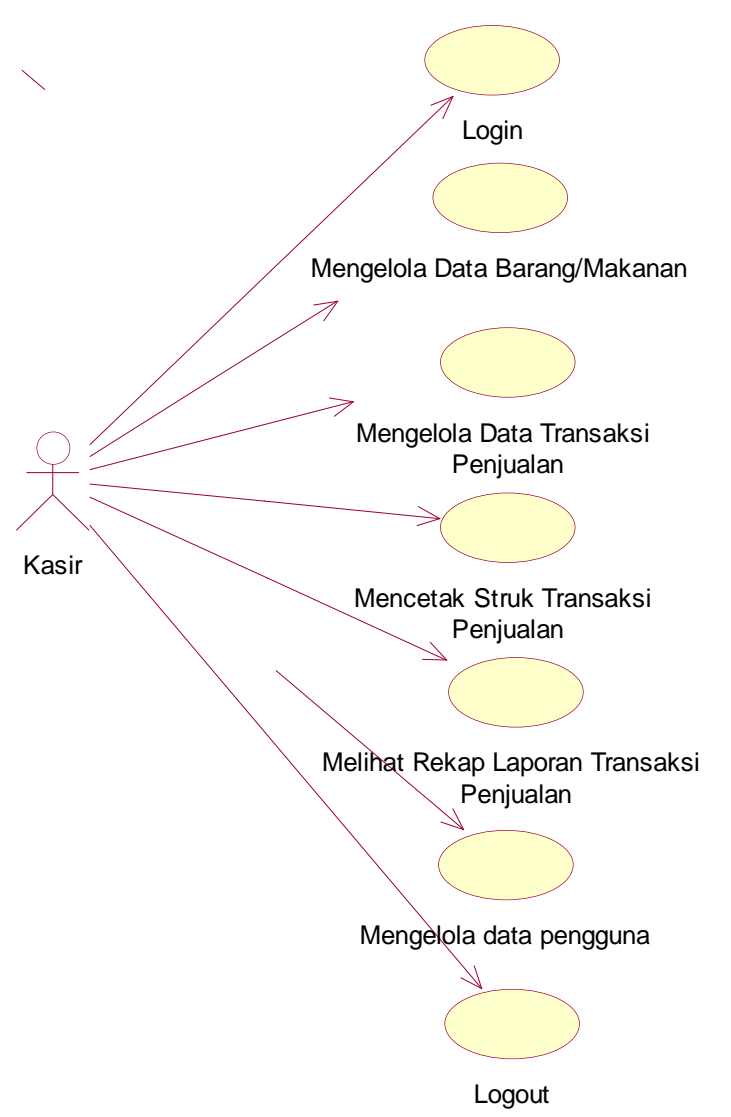

Gambar 1. Use case diagram kasir

\section{Activity Diagram}

Activity diagram digunakan untuk menggambarkan proses bisnis dan urutan aktivitas dalam sebuah proses yang telah dibuat dalam bentuk use case diagram.

\section{Entity Relationship Diagram (ERD)}

$E R D$ digunakan untuk memodelkan struktur data dan hubungan antar data yang ada pada database pada aplikasi backend yang nantinya data yang tersimpan dalam database akan parsing ke aplikasi frontend.

\section{User Interface}

User interface digunakan untuk memberikan gambaran aplikasi kepada user. User interface meliputi struktur menu, input dan output aplikasi, dan fungsi-fungsi yang ada pada aplikasi.

8. Arsitektur Sistem

Arsitektur sistem yang dibangun pada gambar 2 terdiri dari aplikasi kasir Tablet Portable Android. Data disimpan pada database SQLite, transaksi penjualan akan dicetak dengan thermal printer dengan melalui sambungan bluetooth.

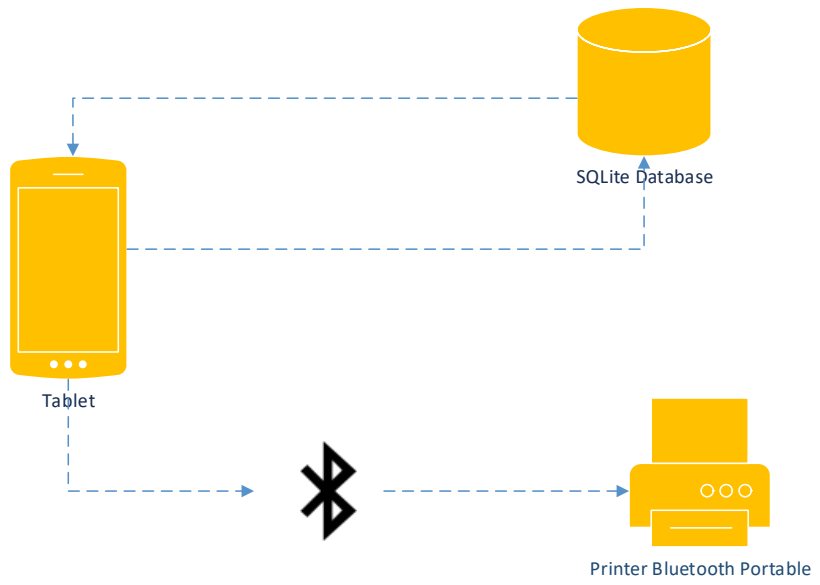

Gambar 2. Arsitektur sistem aplikasi

9. Implementasi

Aplikasi kasir Tablet Portable diimplementasikan dengan menggunakan Android Development Tools (ADT) dengan mengunakan Java sebagai bahasa pemrogramannya dan SQLite database sebagai media penyimpanannya.

Gambar 3 adalah tampilan login, yaitu tampilan awal pada saat aplikasi dijalankan, kemudian akan muncul halaman awal aplikasi yamng menampilkan produk makanan, minuman, snack yang dijual, dan dashboard menu aplikasi.

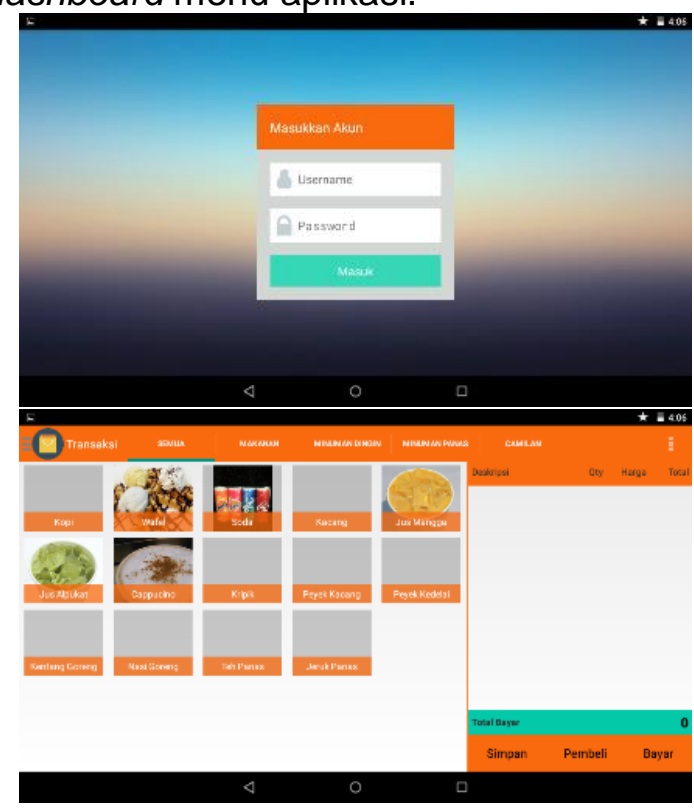

Gambar 3. Tampilan login, halaman awal

Gambar 4 adalah tampilan daftar pembeli. Ketika pembeli melakukan pemesanan dan belum melakukan pembayaran maka akan tampil di halaman 
daftar pembeli yang menampilkan informasi total biaya yang harus dibayarkan.

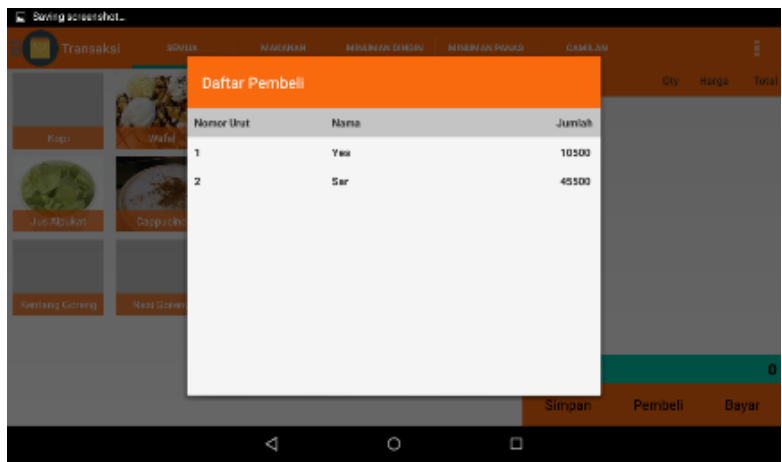

Gambar 4. Tampilan daftar pembeli

Gambar 5 adalah tampilan kelola data makanan yang menampilkan daftar makanan serta minuman yang dapat ditambah, diubah maupun dihapus.

Gambar 6 adalah tampilan halaman laporan. Dalam halaman ini terdapat daftar transaksi, grafik transaksi serta makanan yang paling laris.

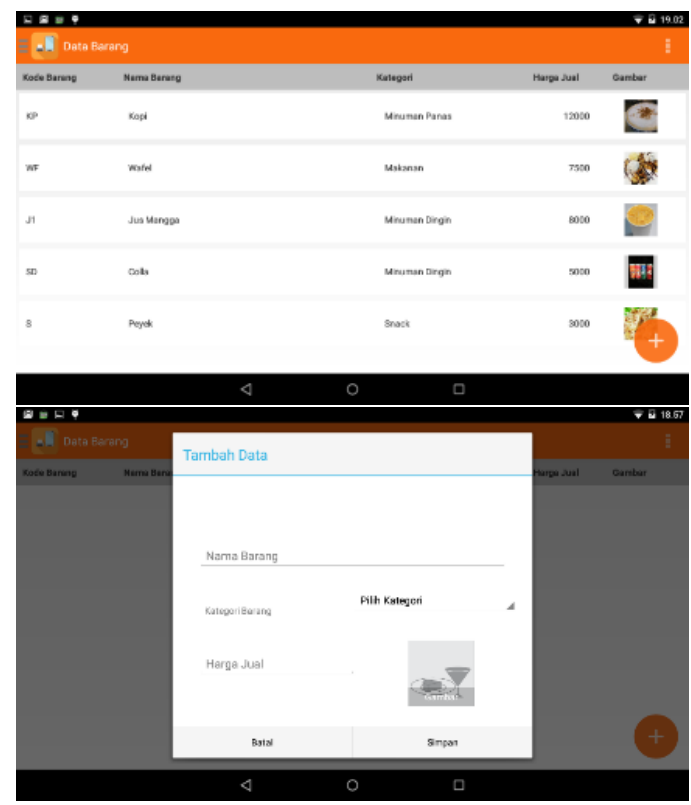

Gambar 5. Tampilan daftar makanan dan tambah makanan

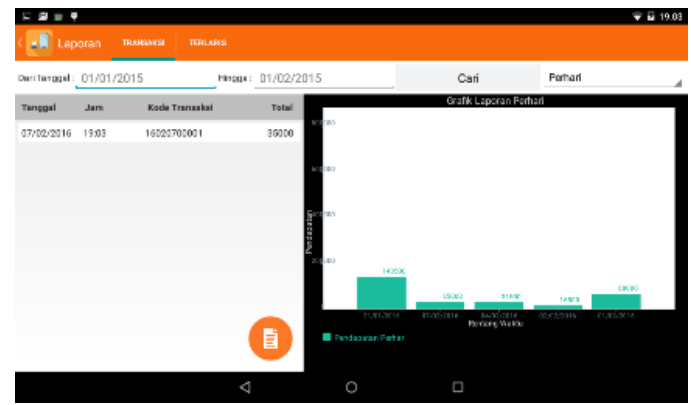

Gambar 6. Tampilan halaman laporan

Gambar 7 merupakan tampilan halaman pengaturan yang didalamnya terdapat tombol kelola kasir atau pengguna, backup database, restore database dan export data kedalam bentuk file csv.

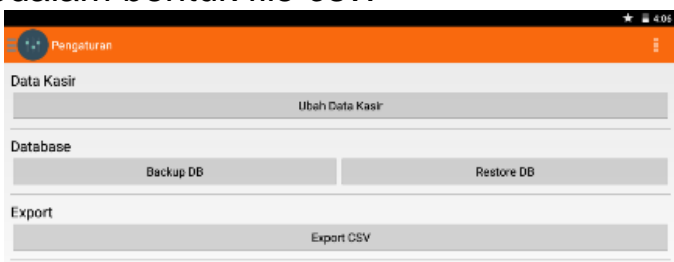

Gambar 7. Tampilan daftar benda koleksi

Gambar 8 merupakan hasil cetak dari transaksi yang dilakukan dengan printer thermal bluetooth.

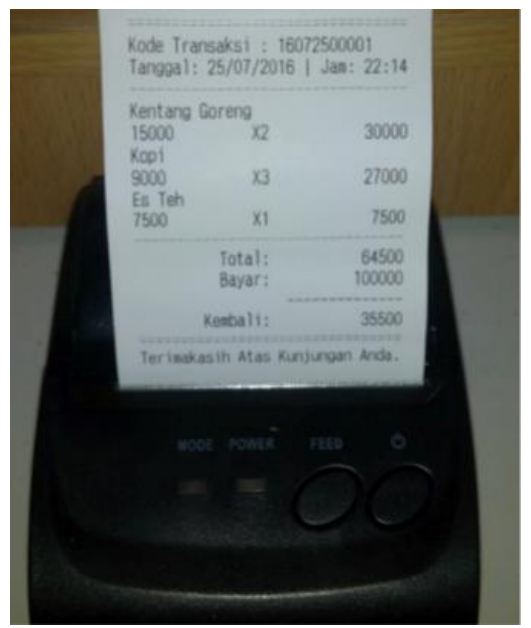

Gambar 8. Hasil cetak transaksi

10. Pengujian Sistem

Dari hasil pengujian unit test menunjukkan aplikasi berjalan dengan lancar tidak ada error dan tidak ada yang fail.

Finished after 0.107 seconds

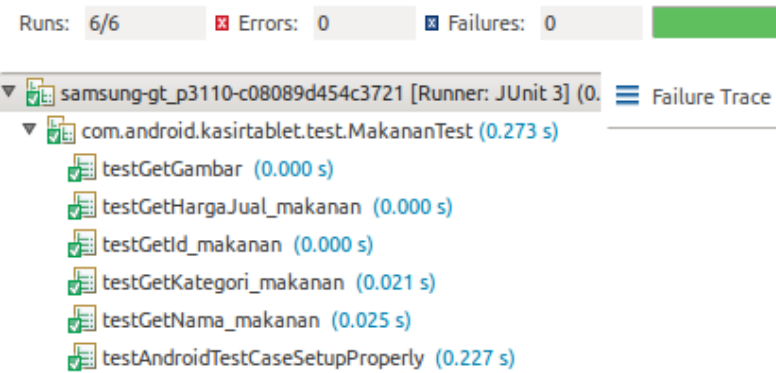

Gambar 9. Hasil pengujian unit test 
Pengujian Unit test dilakukan dengan menguji bagian terkecil dari sebuah code, bagian terkecil ini adalah bisa sebuah fungsi, module atau class dari sistem tersebut. Unit test ini dilakukan dengan menguji class Makanan. Hal ini dilakukan bertujuan untuk memastikan dapat berjalan sesuai yang diharapkan.

Tabel 1. Hasil pengujian black box test

\begin{tabular}{|c|c|c|c|c|}
\hline \multirow{3}{*}{\multicolumn{2}{|c|}{$\begin{array}{cc}\text { Tes } & \text { Function } \\
\text { tID } & \text { Name/ } \\
& \text { Process } \\
& \text { Name }\end{array}$}} & \multirow[b]{3}{*}{ Description } & \multirow[b]{3}{*}{ Expected Results } & \multirow[b]{3}{*}{$\begin{array}{l}\text { Actual } \\
\text { Result }\end{array}$} \\
\hline & & & & \\
\hline & & & & \\
\hline & Login Kasir & \multicolumn{2}{|c|}{$\begin{array}{l}\text { Syarat : Username dan Password saat pertama kali } \\
\text { install aplikasi adalah admin }\end{array}$} & \\
\hline & & $\begin{array}{l}\text { Username dan Password } \\
\text { benar }\end{array}$ & $\begin{array}{l}\text { Tampil pesan "Login } \\
\text { Berhasil" dan keluar } \\
\text { peringatan untuk aktifkan } \\
\text { Bluetooth atau tidak }\end{array}$ & Lulus \\
\hline & & $\begin{array}{l}\text { Username dan atau } \\
\text { Password salah }\end{array}$ & $\begin{array}{l}\text { Tampil pesan "Login } \\
\text { Gagal Pastikan } \\
\text { Username dan Password } \\
\text { Benar" }\end{array}$ & Lulus \\
\hline
\end{tabular}

2. Tambah data makanan

\section{Syarat : sudah melakukan test 1}

Klik menu Data Makanan, klik icon tambah.

Inputan : Nama Makanan, Kategori makanan, Harga, Gambar Klik menu Data Makanan, klik icon tambah Inputan : Nama Makanan, Kategori makanan, Harga, Gambar

\author{
Tampil pesan "Nama \\ Belum Diisi !!!" \\ Tampil pesan kesalahan \\ Tampil pesan "Harga \\ Belum Diisi !!!" \\ Tampil pesan "Data \\ berhasil disimpan" dan \\ tampil data (Nama \\ Makanan, Kategori \\ makanan, Harga, \\ Gambar)

3. Ubah data makanan

\section{Syarat : sudah melakukan test 2}
Klik menu Data Makanan, klik makanan yang akan diubah Inputan : Nama Makanan, Kategori makanan, Harga, Gambar Tampil pesan "Data berhasil diubah"

4. Hapus data makanan

\section{Syarat : sudah melakukan test 2}

Klik menu Data Makanan, klik tahan lama makanan yang akan dihapus
Tampil peringatan "Apakah anda akan menghapus nama makanan?" Jika Ya tampil pesan "nama makanan terhapus" jika tidak 


\begin{tabular}{|c|c|c|c|c|}
\hline $\begin{array}{l}\text { Tes } \\
t I D\end{array}$ & $\begin{array}{l}\text { Function } \\
\text { Name/ } \\
\text { Process } \\
\text { Name }\end{array}$ & Description & Expected Results & $\begin{array}{l}\text { Actual } \\
\text { Result }\end{array}$ \\
\hline \multirow{5}{*}{5.} & \multirow{5}{*}{$\begin{array}{l}\text { Kelola } \\
\text { transaksi }\end{array}$} & & $\begin{array}{l}\text { kembali ke daftar } \\
\text { makanan }\end{array}$ & \\
\hline & & \multicolumn{2}{|c|}{ Syarat : sudah melakukan test 2} & \\
\hline & & $\begin{array}{l}\text { Klik menu transaksi, klik } \\
\text { makanan yang akan } \\
\text { dipesan (klik lagi untuk } \\
\text { menambah/klik makanan } \\
\text { sebelah kanan untuk } \\
\text { mengrangi atau } \\
\text { menghapus), }\end{array}$ & $\begin{array}{l}\text { Tampil makanan yang } \\
\text { dipilih di sebelah kanan } \\
\text { beserta totalnya }\end{array}$ & $\begin{array}{l}\text { Lulus/ } \\
\text { Tidak }\end{array}$ \\
\hline & & $\begin{array}{l}\text { klik bayar, masukkan } \\
\text { nominal uang pembayaran, }\end{array}$ & $\begin{array}{l}\text { Tampil total pembayaran } \\
\text { dan papan intutan } \\
\text { nominal uang } \\
\text { pembayaran }\end{array}$ & Lulus \\
\hline & & klik bayar & $\begin{array}{l}\text { Jika pembayaran kurang } \\
\text { akan muncul peringatan } \\
\text { "pembayaran kurang" dan } \\
\text { jika pembayaran } \\
\text { mencukupi akan tampil } \\
\text { jumlah kembalian dan } \\
\text { Tampil pesan "Data } \\
\text { tersimpan" }\end{array}$ & Lulus \\
\hline \multirow[t]{2}{*}{6.} & \multirow[t]{2}{*}{$\begin{array}{l}\text { Cetak struk } \\
\text { transaksi }\end{array}$} & \multicolumn{2}{|c|}{$\begin{array}{l}\text { Syarat : Sudah melakukan test } 5 \text {, prangkat tablet } \\
\text { terhubung dengan printer bluetooth portable }\end{array}$} & \\
\hline & & $\begin{array}{l}\text { Klik menu transaksi, klik } \\
\text { makanan yang akan } \\
\text { dipesan (klik lagi untuk } \\
\text { menambah/klik makanan } \\
\text { sebelah kanan untuk } \\
\text { mengrangi atau } \\
\text { menghapus), klik bayar, } \\
\text { masukkan nominal uang } \\
\text { pembayaran, klik bayar }\end{array}$ & $\begin{array}{l}\text { Tampil pesan "Data } \\
\text { berhasil disimpan" dan } \\
\text { printer mencetak struk } \\
\text { transaksi }\end{array}$ & Lulus \\
\hline \multirow[t]{3}{*}{7.} & \multirow{3}{*}{$\begin{array}{l}\text { Kelola } \\
\text { Pembeli }\end{array}$} & \multicolumn{2}{|c|}{ Syarat : Sudah melakukan test 2} & \\
\hline & & $\begin{array}{l}\text { Klik menu transaksi, klik } \\
\text { makanan yang akan } \\
\text { dipesan (klik lagi untuk } \\
\text { menambah/klik makanan } \\
\text { sebelah kanan untuk } \\
\text { mengrangi atau } \\
\text { menghapus), klik simpan, } \\
\text { masukkan nama pembeli }\end{array}$ & $\begin{array}{l}\text { Jika nama pembeli sudah } \\
\text { ada akan tampil pesan } \\
\text { "nama sudah dipakai" } \\
\text { dan jika belum tampil } \\
\text { pesan "Pesanan Pembeli } \\
\text { berhasil disimpan" }\end{array}$ & Lulus \\
\hline & & $\begin{array}{l}\text { Klik menu transaksi, klik } \\
\text { antrian, pilih pembeli, (klik } \\
\text { makanan lagi untuk } \\
\text { menambah/klik makanan }\end{array}$ & $\begin{array}{l}\text { Tampil daftar makana } \\
\text { yang dipesan di sebelah } \\
\text { kanan }\end{array}$ & Lululs \\
\hline
\end{tabular}




\begin{tabular}{|c|c|c|c|c|}
\hline $\begin{array}{l}\text { Tes } \\
t \text { ID }\end{array}$ & $\begin{array}{l}\text { Function } \\
\text { Name/ } \\
\text { Process } \\
\text { Name } \\
\end{array}$ & Description & Expected Results & $\begin{array}{l}\text { Actual } \\
\text { Result }\end{array}$ \\
\hline \multirow{5}{*}{8.} & \multirow{5}{*}{$\begin{array}{l}\text { Tampil } \\
\text { laporan }\end{array}$} & \multicolumn{2}{|l|}{$\begin{array}{l}\text { sebelah kanan untuk } \\
\text { mengrangi atau menghapus }\end{array}$} & \\
\hline & & \multicolumn{2}{|c|}{ Syarat : sudah melakukan test 5} & \\
\hline & & $\begin{array}{l}\text { Klik menu laporan } \\
\text { Pilih transaksi } \\
\text { Pilih kategori berdasarkan } \\
\text { (Hari ini, perhari, perbulan, } \\
\text { pertahun) }\end{array}$ & $\begin{array}{l}\text { Tampil data transaksi } \\
\text { Tampil detail transaksi } \\
\text { Tampil grafik sesuai } \\
\text { kategori }\end{array}$ & $\begin{array}{l}\text { Lulus } \\
\text { Lulus } \\
\text { Lulus }\end{array}$ \\
\hline & & $\begin{array}{l}\text { Masukkan rentang tanggal } \\
\text { yang diiginkan }\end{array}$ & $\begin{array}{l}\text { Tampil transaksi sesuai } \\
\text { tanggal yang diinginkan }\end{array}$ & Lulus \\
\hline & & $\begin{array}{l}\text { Klik icon kertas (untuk } \\
\text { export laporan yang } \\
\text { diinginkan) }\end{array}$ & $\begin{array}{l}\text { Tampil pesan "export csv } \\
\text { berhasil ke /sdcard/Kasir } \\
\text { Tablet/Export CSV/ } \\
\text { Laporan_tanggal_jam.csv }\end{array}$ & Lulus \\
\hline \multirow[t]{2}{*}{9.} & $\begin{array}{l}\text { Tampil } \\
\text { Terlaris }\end{array}$ & \multicolumn{2}{|c|}{ Syarat : sudah melakukan test 5} & \\
\hline & & $\begin{array}{l}\text { Klik menu laporan, klik tap } \\
\text { terlaris }\end{array}$ & $\begin{array}{l}\text { Tampil data makanan } \\
\text { terlaris }\end{array}$ & Lulus \\
\hline \multirow[t]{2}{*}{10.} & $\begin{array}{l}\text { Tambah } \\
\text { Kasir }\end{array}$ & \multicolumn{2}{|c|}{ Syarat : sudah melakukan test 1} & \\
\hline & & $\begin{array}{l}\text { Klik menu pengaturan, klik } \\
\text { ubah data kasir, klik icon } \\
\text { tambah } \\
\text { Inputan : username, } \\
\text { password }\end{array}$ & $\begin{array}{l}\text { Jika username sudah } \\
\text { dipakai akan Tampil } \\
\text { pesan "Username sudah } \\
\text { digunakan, jika belum } \\
\text { "Tampil pesan "username } \\
\text { disimpan" tampil data } \\
\text { kasir }\end{array}$ & Lulus \\
\hline \multirow[t]{2}{*}{11.} & $\begin{array}{l}\text { Ubah data } \\
\text { kasir }\end{array}$ & \multicolumn{2}{|c|}{ Syarat : sudah melakukan test 10} & \\
\hline & & $\begin{array}{l}\text { Klik menu pengaturan, klik } \\
\text { ubah data kasir, pilih } \\
\text { username yang akan } \\
\text { diubah } \\
\text { Inputan : username, } \\
\text { password }\end{array}$ & $\begin{array}{l}\text { Jika username sudah } \\
\text { dipakai akan Tampil } \\
\text { pesan "Username sudah } \\
\text { digunakan, jika belum } \\
\text { Tampil pesan"Data Kasir } \\
\text { berhasil diubah" tampil } \\
\text { data kasir }\end{array}$ & Lulus \\
\hline \multirow[t]{2}{*}{12.} & Hapus & \multicolumn{2}{|c|}{ Syarat : sudah melakukan test 10} & \\
\hline & & $\begin{array}{l}\text { Klik menu pengaturan, klik } \\
\text { ubah data kasir, klik tahan } \\
\text { lama username yang akan } \\
\text { dihapus }\end{array}$ & $\begin{array}{l}\text { Tampil peringatan } \\
\text { "Apakah anda akan } \\
\text { menghapus username?" } \\
\text { Jika Ya tampil pesan } \\
\text { "username terhapus" jika } \\
\text { tidak kembali ke daftar } \\
\text { Kasir }\end{array}$ & Lulus \\
\hline 13. & $\begin{array}{l}\text { Backup } \\
\text { Database }\end{array}$ & \multicolumn{2}{|c|}{ Syarat : sudah melakukan test 1} & \\
\hline
\end{tabular}




\begin{tabular}{|c|c|c|c|c|}
\hline $\begin{array}{l}\text { Tes } \\
\text { t ID }\end{array}$ & $\begin{array}{l}\text { Function } \\
\text { Name/ } \\
\text { Process } \\
\text { Name }\end{array}$ & Description & Expected Results & $\begin{array}{l}\text { Actual } \\
\text { Result }\end{array}$ \\
\hline \multirow{3}{*}{14.} & \multirow{3}{*}{$\begin{array}{l}\text { Restore } \\
\text { Database }\end{array}$} & $\begin{array}{l}\text { Klik menu pengaturan, klik } \\
\text { Backup Database }\end{array}$ & $\begin{array}{l}\text { Tampil pesan "Backup } \\
\text { database berhasil } \\
\text { /sdcard/Kasir Tablet/ } \\
\text { Backup Database/ } \\
\text { Backup Data } \\
\text { Kasir_tanggal_jam.db/" }\end{array}$ & Lulus \\
\hline & & \multicolumn{2}{|c|}{ Syarat : sudah melakukan test 1} & \\
\hline & & $\begin{array}{l}\text { Klik menu pengaturan, klik } \\
\text { Restore Database, pilih } \\
\text { direktori database disimpan } \\
\text { Svarat : sudah melakukan }\end{array}$ & $\begin{array}{l}\text { Tampil pesan "Restore } \\
\text { berhasil" }\end{array}$ & Lulus \\
\hline 15. & & $\begin{array}{l}\text { Klik menu pengaturan, klik } \\
\text { export csv (untuk export } \\
\text { seluruh laporan) }\end{array}$ & $\begin{array}{l}\text { Tampil pesan "export csv } \\
\text { berhasil ke /sdcard/Kasir } \\
\text { Tablet/Export CSV/ } \\
\text { Laporan Semua } \\
\text { Transaksi_tanggal_jam.c } \\
\text { sv" }\end{array}$ & Lulus \\
\hline
\end{tabular}

Dari pengujian black box test dapat disimpulkan bahwa aplikasi berjalan sesuai dengan apa yang telah dirancang.

\section{KESIMPULAN}

Berdasarkan hasil penelitian dan pembahasan, maka dapat disimpulkan halhal sebagai berikut:

1. Penelitian ini telah menghasilkan sebuah aplikasi Kasir Portable yang dimanfaatkan untuk membantu proses transaksi penjualan, menggantikan rekapitulasi pendapatan yang dilakukan secara manual kedalam bentuk file excel oleh kasir Kafe dan mencetak bukti pembayaran atau struk transaksi yang efisien karena terintegrasi dengan printer bluetooth.

2. Berdasarkan hasil pengujian unit test sebanyak 5 method, method dari class makanan sudah berjalan dengan lancar tidak ada method yang error maupun fail sehingga dapat dinyatakan lolos dan pengujian black box test dapat disimpulkan bahwa aplikasi berjalan sesuai dengan apa yang telah dirancang.

\section{DAFTAR PUSTAKA}

D. A. Hidayat, "Rancang Bangun Aplikasi Point Of Sale (POS) Berbasis Web dengan Pemanfaatan Trigger Pada Distribution Store Cv. Nmrq," Univ. Tanjungpura, 2014.

D. Jeafri, Yofi Okta; Lulu W, Yohana Dewi; Nurmalasari, "Aplikasi Financial Record Income dan Expense Untuk Usaha Perkantoran dengan Menggunakan Metode Common Size Berbasis Android (Studi Kasus: Toko Bintang Satu)," Poltek Caltex Riau, 2012.

E. Setiawan, "Kamus Besar Bahasa Indonesia (KBBI) Online - arti kata kafe," KBBI ONLINE, 2012. [Online]. Available: http://kbbi.web.id/kafe. [Accessed: 16-Apr-2015].

Hendry, Membangun Aplikasi Point Of Sale dengan VB 6.0, MySQL, dan PHP. Jakarta: Elex Media Komputindo, 2010.

I. A. R. Ginting, "Rancang \& Implementasi Point Of Sales (POS) Berbasis Web Pada Distro Previous," STMIK AMIKOM Yogyakarta, 2011.

K. Goenawan, Izin Beres Bisnis Sukses. Yogyakarta: Pustaka Grahatama, 
2008

L. Jamal, Ahmad; Yulianto, "Rancang Bangun Sistem Informasi Aplikasi Kasir Menggunakan Barcode Reader Pada Toko dan Jasa Widodo Computer Ngadiharjo Kabupaten Pacitan," Indones. J. Comput. Sci., 2013.
M. I. M. E. Putra, "Aplikasi Ponsel Berbasis Android untuk Penjualan Pada Kios Eceran Q-Mono Flower," STMIK AMIKOM Yogyakarta, 2012.

Y. Supardi, Semua Bisa Menjadi PROGRAMMER Android Case Study. Jakarta: Elex Media Komputindo, 2014. 